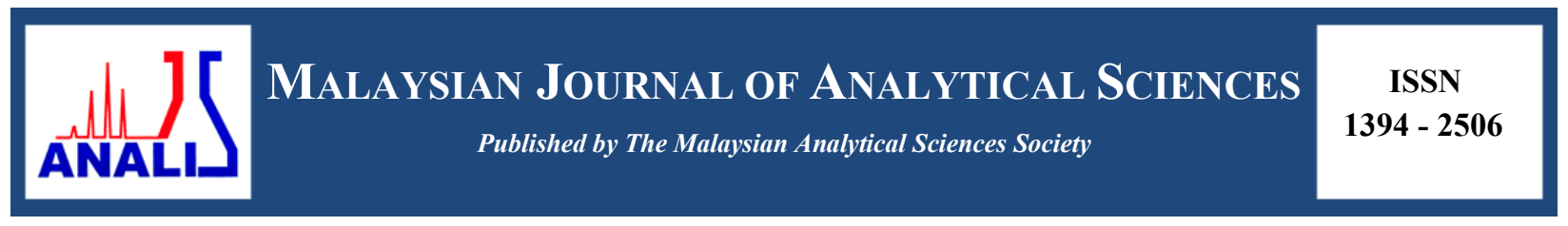

\title{
DESALINATION OF SEAWATER USING NEWLY FABRICATED NANOFILTRATION FLAT SHEET MEMBRANE
}

\author{
(Penyahgaraman Air Laut Menggunakan Rekaan Baru Membran Kepingan Rata Penapisan \\ Nano)
}

\author{
Wan Syarizawani Wan Chik ${ }^{1 *}$, Mohd Johan Mohamed Ibrahim ${ }^{1}$, Ramlah Mohd Tajuddin ${ }^{2}$ \\ ${ }^{I}$ Faculty of Civil Engineering, \\ Universiti Teknologi MARA Cawangan Johor, Kampus Pasir Gudang, 85000 Segamat, Johor, Malaysia \\ ${ }^{2}$ Faculty of Civil Engineering, \\ Universiti Teknologi MARA, 40450 Shah Alam, Selangor, Malaysia. \\ *Corresponding author: zawani9681@johor.uitm.edu.my
}

Received: 4 December 2016; Accepted: 1 December 2017

\begin{abstract}
Desalination is one of the technologies to produce clean water for drinking, irrigation, industrial and development. Generally desalination can be classified based on their separation mechanisms which are thermal and membrane based desalination. In this study the newly fabricated nanofiltration membrane was used to identify their performance in desalination process. The material chosen in this study is polysulfone (PSf), N-methyl-2-pyrolidon (NMP) and polyvinylpyrrolidone (PVP). The dope solution composition was determined by using titration method. The membrane compositions are 20:1:79, 20:2:78, 20:3:77 and 20:4:76 (weight ratio) for PSf/PVP-1\%, PSf/PVP-2\%, PSf/PVP-3\% and PSf/PVP-4\% respectively. The polysulfone membrane was fabricated by wet phase inversion method. The aims of this research are to investigate the effect of different PVP concentrations in material composition on membrane morphology, membrane fluxes and seawater rejection. The results observed by SEM show the membrane composition PSf/PVP-1\% has lower pore size with average pore size $8.4 \mathrm{~nm}$ while PSf/PVP-4\% has highest pore size. Membrane PSf/PVP-1\% has highest rejection (5.7\%) and lower flux $\left(2.43 \mathrm{~L} / \mathrm{cm}^{2}\right.$.hr) while PSf/PVP-4\% has highest flux $\left(6.44 \mathrm{~L} / \mathrm{cm}^{2} . \mathrm{hr}\right)$ and lower rejection $(0.87 \%)$. It is related with PVP contents in the membrane solution. In conclusion, increase PVP concentration will increase pore size, therefore it will increase flux while the rejection will decrease.
\end{abstract}

Keywords: membrane based desalination, nanofiltration, polysulfone, polyvinylpyrrolidone

\begin{abstract}
Abstrak
Penyahgaraman adalah salah satu teknologi untuk menghasilkan air bersih untuk minuman, pengairan, perindustrian dan pembangunan. Secara umumnya penyahgaraman boleh dikelaskan berdasarkan mekanisme pengasingan iaitu penyahgaraman berdasarkan terma dan membran. Dalam kajian ini membran penapisan nano yang baru direka telah digunakan untuk mengenal pasti prestasi dalam proses penyahgaraman. Bahan dipilih dalam kajian ini adalah polisulfon (PSf), N-metil-2-pirolidon (NMP) dan polivinilpirolidon (PVP). Komposisi cecair larutan yang telah ditentukan adalah menggunakan kaedah titratan. Komposisi membran yang digunakan ialah 20:1:79, 20:2:78, 20:3:77 dan 20:4:76 (nisbah berat) untuk PSf/PVP-1\%, PSf/PVP-2\%, PSf/PVP-3\% dan PSf/PVP-4\%. Membran polisulfon dihasilkan melalui kaedah fasa penyongsangan basah. Tujuan kajian ini adalah untuk mengkaji kesan kepekatan PVP berbeza dalam komposisi bahan morfologi membran, fluks membran dan penyingkiran air laut. Keputusan dipatuhi oleh SEM menunjukkan membran komposisi PSF/PVP-1\% mempunyai saiz liang yang lebih kecil dengan purata saiz liang $8.4 \mathrm{~nm}$ manakala PSF/PVP-4\% mempunyai saiz liang terbesar. Membran PSF/PVP-1\% mempunyai penyingkiran tertinggi (5.7\%) dan fluks yang lebih rendah $(2.43 \mathrm{~L} / \mathrm{cm} 2 . \mathrm{hr})$ manakala PSF/PVP $-4 \%$ mempunyai fluks tertinggi $(6.44 \mathrm{~L} / \mathrm{cm} 2 . \mathrm{hr})$ dan penyingkiran yang lebih rendah $(0.87 \%)$. Ia berhubungkait dengan kandungan PVP dalam larutan membran. Kesimpulannya, peningkatan kepekatan PVP akan meningkatkan saiz liang, oleh itu ia akan meningkatkan fluks manakala penyingkiran akan berkurangan.
\end{abstract}




\section{Wan Syarizawani et al: DESALINATION OF SEAWATER USING NEWLY FABRICATED \\ NANOFILTRATION FLAT SHEET MEMBRANE}

Kata kunci: penyahgaraman berdasarkan membran, penapisan nano, polisulfon, polivinilpirolidon

\section{Introduction}

Water is an important component in our daily life besides water is a natural resource that covers $75 \%$ of the earth's surface. However from all the water resources only 3\% is for potable usage [1]. Nowadays the most serious problem affecting people around the world is global water crisis. The increasing of population and development will increase the demand on the quantity and quality of drinking water. It is projected that by year 2030, the global demand of water would increase from 4500 billion $\mathrm{m}^{3}$ to 6900 billion $\mathrm{m}^{3}$ [2]. Therefore, the future needs of water resources are higher than the current surface water resources available. Nowadays membrane desalination technology such as reverse osmosis (RO), nanofiltration (NF) and membrane distillation (MD) are the most popular membrane based technology used for saline water treatment. At present more than $50 \%$ of the world's desalination water is produced by membrane technology [3]. Respect to that NF has potential in the desalination process due to development of new membrane material and novel process, furthermore NF will enhanced flux, lower operational pressure and energy saving compare with RO system [4]. Membrane materials with high permeability and selectivity, and advanced of fabrication technologies to produce membrane with a defect free ultrathin dense selective layer are the primary focuses for most membrane technologist. Significant progresses have been made in membrane materials, dope preparation, fabrication technique and fundamental understanding of membrane formation. Choosing appropriate membrane materials is one of the key factors to the success of membrane performance. Basically, for producing asymmetric membrane structure, components that must consist in the dope formulation are polymer, solvent and additive. Introduced second polymer in the solution will improve the properties of polymer and produced high porous membrane. In this study the polyvinylpyrrolidone (PVP) was chosen as additional polymer in the membrane material solutions because of their characteristics. The PVP will control morphology from both thermodynamics and kinetics aspects [5]. Study of Chakrabarty et al. showed that the additional PVP in the solution increase the pore number as well as porosity of the prepared membrane [6].

\section{Materials}

\section{Materials and Methods}

Membranes material used in this study consists of polymer, solvent and additive. Polymer used in this study to fabricate nanofiltration flat sheet membrane is polysulfone (PSf). Polysulfone was chosen as main component because of their characteristics and advantages. PSf is widely used as a component in the fabrication of membrane because of its excellent balance of chemical, thermal and mechanical properties [7]. Besides it has good chemical and temperature stability up to $80{ }^{\circ} \mathrm{C}$ and $\mathrm{pH}$ range from 1.5 to 12 for cleaning [8]. Although it shows some tolerance to oxidizing agents such as chlorine and ability to retain their mechanical properties in hot and wet environments. The solvent used to prepare dope solution was N-methyl-2-pyrolidon (NMP). NMP was used because this solvent able to dissolved in several types of polymers. The casting solution based on this solvent can precipitate rapidly when immersed in the water and resulting porous and very anisotropic membranes [9]. Additive is introduced in the polymer solution to improve the properties of polymer membranes. Additive used in this study was polyvinylpyrrolidone (PVP). According to Yoo et al. adding the second polymer in the solution produced high porous membranes, well interconnected pores and surface properties [10]. PVP was chosen because of their benefits. The PVP will control morphology from both thermodynamics and the kinetics aspects [11]. Thus in the thermodynamics, it makes the system unstable and prone to phase separation. Then in kinetics, the high viscosity of the polymer solution after the addition of PVP will delay the phase separation and slow down the demixing process. The final result was the trade-off between two effects $[12,13]$.

\section{Methods}

Membrane fabrications have several processes to complete, firstly the dope formulation was determined and specified formulation was recorded. The dope solution was mixed before the casting process. After the casting process the flat sheet membrane was immersed in the coagulation bath and finally membrane was stored in the water bath for a day before dry at room temperature. 
Seawater $(25 \mathrm{~L})$ was prepared in the feed tank as feed solution. The physical and chemical characteristics of seawater were tested in the environmental laboratory. The physical parameter tested were color, temperature, turbidity, conductivity, total dissolved solid and total suspended solid while chemical parameter tested were $\mathrm{pH}$ and dissolved oxygen (DO).

Membrane separation process was conducted using laboratory scale cross flow filtration system. The seawater was prepared as feed solution. Pure water also prepared as feed solution to compare their membrane performance. Membrane sample was fractured into small size to fix the flat sheet membrane. Then the pressure was setup at 2 bar or 30 psi to pump so that the feed solution will pass through the membrane. The feed solution was maintained at room temperature which is $25-30{ }^{\circ} \mathrm{C}$. After that permeate and rejection concentration was determined. Permeate and rejection concentration was tested by using conductivity meter in order to determine the concentration after the filtration process.

\section{Membrane dope formulation}

\section{Results and Discussion}

The PVP concentration used in this study is the range 1to 4 (wt\%) as show in Table 1. Based on Han et al. studied, by adding PVP in PSf casting solution the thermodynamic and rheological properties will varies [14]. The result indicated that when adding low content PVP (below $5 \mathrm{wt} \%$ ), the variation in thermodynamic property controlled the demixing process and led to the enhancement of phase separation. With further increment of PVP content, the demixing process was delayed due to high viscosity of the casting solution. Based on the four membrane prepared with different percentage of PVP in the material solution. The result show membrane PSf $/$ PVP-1\% give highest performance compared to other membrane. This because, PVP will affect the membrane morphology thus it will influence the membrane flux and seawater rejection.

Table 1. Membrane dope formulation

\begin{tabular}{lccc}
\hline \multirow{2}{*}{ Membrane } & \multicolumn{3}{c}{ Solution Composition (wt\%) } \\
\cline { 2 - 4 } & PSf & PVP & NMP \\
\hline PSf 1 & 20 & 1 & 79 \\
PSf 2 & 20 & 2 & 78 \\
PSf 3 & 20 & 3 & 77 \\
PSf 4 & 20 & 4 & 76 \\
\hline
\end{tabular}

\section{Effect of membrane composition on membrane morphology}

Four membrane PSf prepared by different amount of PVP was observed by Scanning Electron Microscope (SEM) to identify their morphology. Table 2 shows the images observed by SEM at magnification 7000x and 25000x. The images show pore size of the membrane was increase with increase the percentage of PVP in the material compositions. From the Table 2 highest percentage of PVP in the material composition (4\%) give highest pore size $(18.6 \pm 2.1 \mathrm{~nm})$ while lowest percentage of PVP $(1 \%)$ give lowest pore size $(8.4 \pm 1.2 \mathrm{~nm})$. Increase the PVP content in the membrane solution will increase the surface membrane pore size, it happened because of, after the casting film on a glass plate, pre evaporation began and water intake occurred at the top layer of the casting film [15]. Water soluble PVP could migrate and aggregate to the casting film/water interface in order to minimize the interfacial energy. The aggregation of PVP formed polymer lean phase, which might be the rudiment of pore structure on membrane surface and top layer. After immersing the casting film into the coagulation bath, it could induce the formation and growth of pore structure $[16,17]$ 
Table 2. Surface pore size of PSf membrane with different amount of additive

\begin{tabular}{|c|c|c|c|c|}
\hline \multirow{2}{*}{$\%$ PVP } & \multicolumn{4}{|c|}{ Membrane Surface Pore Size (nm) } \\
\hline & 1 & 2 & 3 & 4 \\
\hline \multicolumn{5}{|l|}{$7000 x$} \\
\hline \multicolumn{5}{|l|}{$25000 x$} \\
\hline & $8.4 \pm 1.2$ & $11.2 \pm 1.5$ & $15.5 \pm 1.9$ & $18.6 \pm 2.1$ \\
\hline
\end{tabular}

\section{Membrane cross section}

The prepared four membrane samples were characterized using Scanning Electron Microscope. SEM analysis showed the images of cross section structure of asymmetric nanofiltration membrane PSf/PVP at different composition of PVP as show in Figure 1 and 2. It was found that all the membrane exhibits typical morphological structure of asymmetric membrane which consists of dense top layer and porous sub layer containing macro voids, pores and micro voids. This sub layer formation is controlled by variable of polymer dope solution such as compositions, coagulant temperature and additives [18]. Based on Table 2 the increasing of PVP concentrations in the solution increase the pore size while the cross section for all membranes prepared have same typical asymmetric membrane morphology.

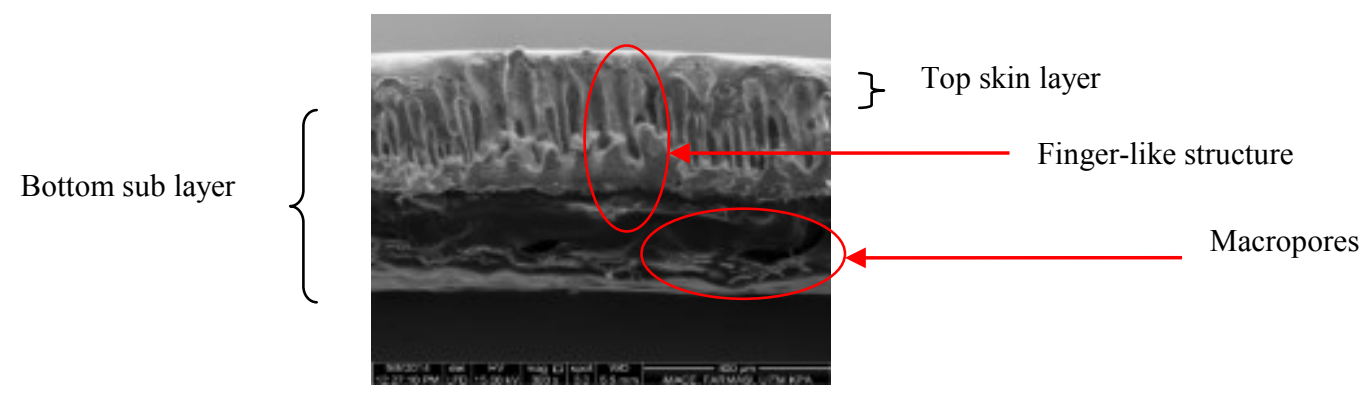

Figure 1. Morphology of PSf/PVP - 4\%

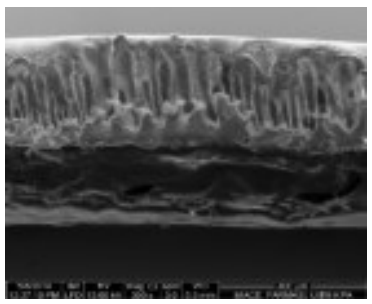

(a) PSf/NMP/PVP- $1 \%$

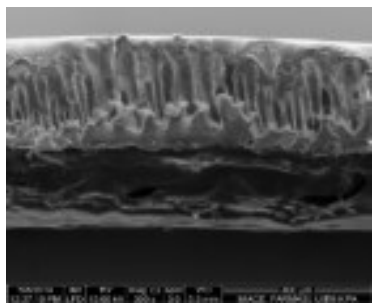

(b) PSf/NMP/PVP- $2 \%$ 


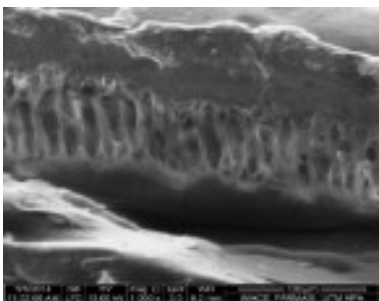

(c) PSf/NMP/PVP- 3\%

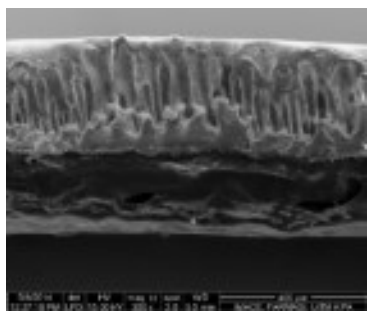

(d) PSf/NMP/PVP- 4\%

Figure 2. SEM micrograph of cross sectional view of PSf/NMP/PVP membrane; (a) PSf/NMP/PVP- 1\%; (b) PSf/NMP/PVP- 2\%; (c) PSf/NMP/PVP- 3\%; (d) PSf/NMP/PVP- 4\%

\section{Effect of PVP concentration in membrane composition on membrane flux}

Figure 3 shows the membrane flux for different percentage of the PVP content. Pure water fluxes of PSf/PVP membranes increase gradually with increasing PVP content, which is probably due to increase of surface hydrophilicity, surface pore size, porosity, acicular pores and macrovoids. It clearly shows that membrane with highest percentage of PVP content $(4 \%)$ will give highest flux $\left(6.44 \mathrm{~L} / \mathrm{cm}^{2} . \mathrm{hr}\right)$ while membrane with lowest percentage of PVP $(1 \%)$ give lowest flux $\left(2.43 \mathrm{~L} / \mathrm{cm}^{2} . \mathrm{hr}\right)$. Based on the discussion on membrane morphology membrane with more percentage of PVP content will increase the membrane pore size, therefore the increase of pore size will increase the membrane flux, hence it will increase the membrane performance. This is related with the aggregation of PVP in the casting film interface during pre evaporation and the pore forming effect of PVP after immersing the casting film into coagulation bath. It has been accepted worldwide that PVP other than its hydrophilic characteristic that able to attract water, it also known as a pore forming agent which in this case is responsible to produce bigger pore in membrane structure.

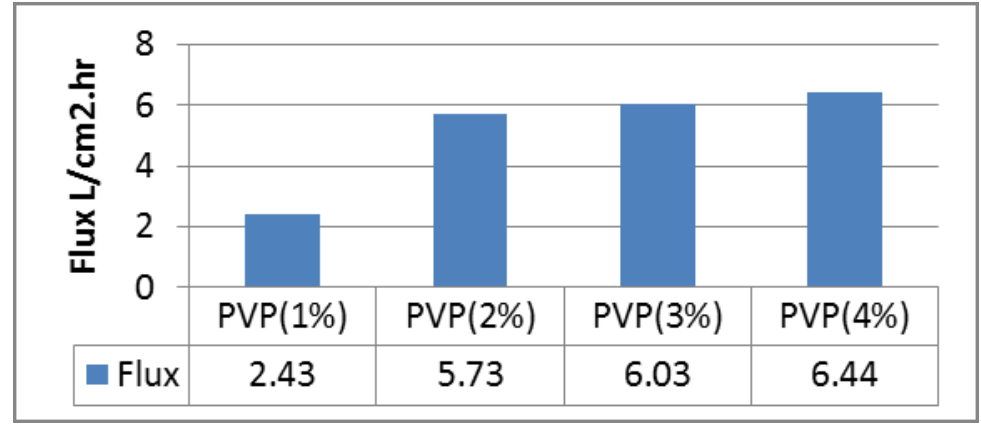

Figure 3. Membrane flux with different \% PVP concentration.

\section{Effect of PVP concentration in membrane composition on seawater rejection}

Table 3 shows the concentration before and after membrane separation process. Based on the result, the concentration of seawater was decrease after separation process for all membrane types. Figure 4 shows membrane with lowest percentage of PVP (1\%) gives highest rejection $(5.7 \%)$ while membrane with highest percentage of PVP $(4 \%)$ gives lowest rejection $(0.87 \%)$. These results are consistent with the SEM characteristics. Membrane morphology show increase percentage of PVP in the material composition will increase the pore size while decrease the percentage of PVP will decrease the pore size. It can be seen that pure water fluxes of membranes increased while seawater rejection decrease obviously, which probably due to the increase of the surface pore size. 
Table 3. Concentrations of seawater before and after membrane separation process

\begin{tabular}{ccccc}
\hline & $\begin{array}{c}\text { Pressure } \\
\text { (bar) }\end{array}$ & $\begin{array}{c}\text { Feed (Cf) } \\
\text { g/l }\end{array}$ & $\begin{array}{c}\text { Permeate (Cp) } \\
\text { g/l }\end{array}$ & Rejection \% \\
\hline PSf/PVP-1\% & 2 & 23 & 21.7 & 5.7 \\
PSf/PVP-2\% & 2 & 23 & 22 & 4.3 \\
PSf/PVP-3\% & 2 & 23 & 22.2 & 3.5 \\
PSf/PVP-4\% & 2 & 23 & 22.8 & 0.87 \\
\hline
\end{tabular}

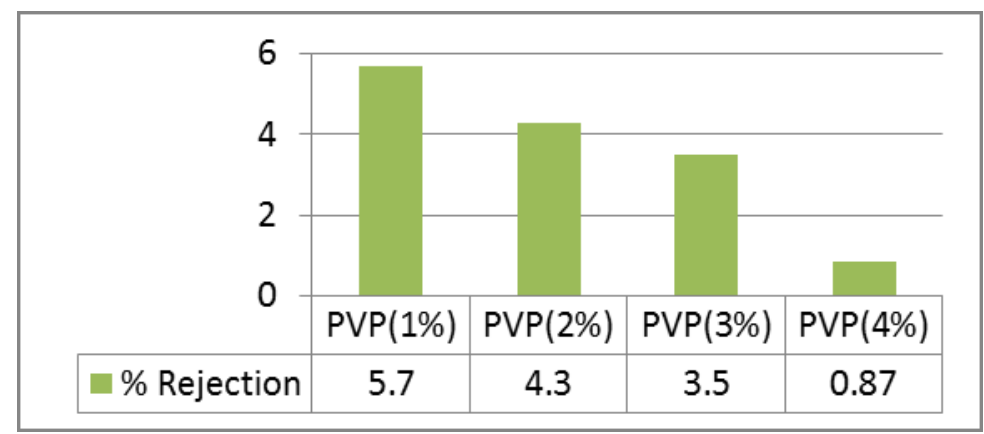

Figure 4. Percentage of seawater rejection with different \% PVP content

\section{Conclusion}

The morphology of the membrane was observed by SEM. The top surface of the membrane was imaged at 7000x and 25000x magnification for all membrane. The result show the pore size was increase with increase of PVP content in the membrane solution. The cross section of all type of membranes show typical asymmetric membrane structure which consist of dense top layer and porous sub layer containing macro voids, pores and micro voids. The membrane composition PSf/PVP-1\% with composition 20:1:79 (weight ratio) PSf/PVP/NMP has lower pore size with average pore size of $8.4 \mathrm{~nm}$. Compared with PSf/PVP-4\% with composition 20:4:76 (weight ratio) that have the highest pore size. Membrane PSf/PVP-1\% has the highest rejection $(5.7 \%)$ and lower flux $\left(2.43 \mathrm{~L} / \mathrm{cm}^{2} . \mathrm{hr}\right)$ while PSf/PVP- $4 \%$ has the highest flux $\left(6.44 \mathrm{~L} / \mathrm{cm}^{2}\right.$.hr) and lower rejection $(0.87 \%)$. It is related with PVP content in the membrane solution. Increase PVP content will increase pore size, therefore it will increase flux while decrease the PVP content will decrease the pore size, therefore it will decrease flux but increase rejection

\section{References}

1. Ioannis, C., Karagiannis, P. and Soldatos, G. (2008). Water desalination cost literature: Review and assessment. Desalination, 223: 448-456.

2. Misdan, N., Lau, W. J. and Ismail, A. F. (2012). Seawater reverse osmosis (SWRO) desalination by thin-film composite membrane-current development, challenges and future prospects. Desalination, 287: 228-237.

3. Altaee, A., Zaragoza, G. and Tonningen, H. R. V. (2014). Comparison between forward osmosis-reverse osmosis and reverse osmosis processes for seawater desalination. Desalination, 336: 50-57.

4. Fang, Y., Bian, L., Bi, Q., Li, Q. and Wang, X. (2014). Evaluation of the pore size distribution of a forward osmosis membrane in three different ways. Journal of Membrane Science, 454: 390-397.

5. Zhao, S., Wang, Z., Wei, X., Tian, X., Wang, J., Yang, S. and Wang, S. (2011). Comparison study of the effect of PVP and PANI nanofiber additives on membrane formation mechanism, structure and performance. Journal of Membrane Science, 385-386: 110-122.

6. Chakrabarty, B., Ghoshal, A. K. and Purkait, M. K. (2008). Preparation, characterization and performance studies of polysulfone membranes using PVP as an additive. Journal of Membrane Science, 315: 36-47. 
7. Song, H. J. and Kim, C. K. (2013). Fabrication and properties of ultrafiltration membranes composed of polysulfone and poly (1-vinypyrrolidone) grated silica nanoparticles. Journal of Membrane Science, 444: 318326.

8. Derya, Y. and Koseoglu, L. (2013). The determination of performances of polysulfone (PS) ultrafiltration membranes fabricated at different evaporation temperatures for the pretreatment of textile wastewater. Desalination, 316: 110-119.

9. Sener, T., Okumus, E., Gurkan, T. and Yilmaz, T. (2010). The effect of different solvents on the performance of zeolite filled composite prvaporation membranes. Desalination, 261: 181-1185.

10. Yoo, S. H., Kim, J. K., Jho, J. Y., Won, J. and Kang, Y. S. (2004). Influence of the addition of PVP on the morphology of asymmetric polyimide phase inversion membranes: effect of PVP molecular weight. Journal of Membrane Science, 236: 203-207.

11. Zhao, S., Wang, Z., Wei, X., Tian, X., Wang, J., Yang, S. and Wang, S. (2011). Comparison study of the effect of PVP and PANI nanofiber additives on membrane formation mechanism, structure and performance. Journal of Membrane Science, 385-386: 110-122.

12. Zhang, P. Y., Wang, Y. L., Xu, Z. L. and Yang, H. (2011). Preparation of poly(vinybutyral) hollow fiber ultrafiltration membrane via wet spinning method using PVP as additive. Desalination, 278: 186-193.

13. Dieling, Z., Jian, Z., Kang, L. and Tai, S. (2017). Fluorographite modified PVDF membranes for seawater desalination via direct contact membrane distillation. Desalination, 413: 119-126.

14. Han, J., Yang, D., Zhang, S. and Jian, X. (2009). Effect of dope compositions on the structure and performance of PPES hollow fiber ultrafiltration membranes. Journal of Membranes Science, 345: 257-266.

15. Guan, R., Dai, H., Li, C., Liu, J. H. and Xu, J. (2006). Effect of casting solvent on the morphology and performance of sulfonated polyethersulfone membranes. Journal of Membrane Science, 277: 148-156.

16. Hu, D., Xu, Z. L., Wei, Y. M. and Liu, Y. F. (2014). Poly(styrene sulfonic acid) sodium modified nanofiltration membranes with improved permeability for the softening of highly concentrated seawater. Desalination, 336: 179-186.

17. Alireza, Z., Ahmad, R. and Mathias, U. (2017). Nano-sized metal organic framework to improve the structural properties and desalination performance of thin film composite forward osmosis membrane. Journal of Membrane Science, 531: 59-67.

18. Baker, R.W. (2004). Membrane technology and application. Membrane technology and research. John Wiley \& Son Inc.: pp. 17-81. 